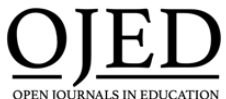

Volume 4, Issue 1 (2020), pp. 59-64

International Journal of

Entrepreneurship and Economic Issues

ISSN: 2616-0048 Print/ ISSN: 2631-231X Online

\section{When Cultures Collide: Global Cultural Intelligence in the Age of Covid-19}

\author{
Clea Patrick \\ Bruce Haselrig \\ Bruce Haselrig Group: Diversity Training, USA
}

\begin{abstract}
The first step is to consider that the " $p$ " in pandemic means a type of passport, a passport to recovery, passport to resurgence, but a passport to a direction in which the leaders' respective messages guide the local response. The ' $p$ ' is a passport to a global new normal, yet culturally competent leaders must set the path that will circumvent further ruin. Closing borders and restricting travel to other countries and states to control the spread of COVID-19 are strategies that should reflect decisions made by culturally intelligent leadership. Therefore, this paper will reflect on the past successes of global collaboration, and the current medley of responses from various countries to deal with COVID-19.
\end{abstract}

Keywords: Covid-19, cultural intelligence, leadership

${ }^{66} \mathrm{Cultural}$ intelligence is the ability to adapt to various cultural contexts and function in different cultural settings or with those of a different culture in one's setting" (Kannan, 2018, p.1). Cultural intelligence is a combination of emotional and social intelligence that is acquired through the maturation 
process of observing and analyzing how people function in different societal situations. Further, the application of culture on the emotional and social intelligence generates human understanding and culturally informed solutions within the cultural context (Kannan, 2018).

\section{MAIN ARUGMENT}

Global citizens need to comprehend the value of applying cultural intelligence as this global COVID-19 pandemic infiltrates all seven continents. The nexus of this cultural collision is presumably the day-in-thelife activities in a Wuhan, China wet market. World travelers to Mexico City, Istanbul, Toronto, San Francisco, and other international destinations know that wet and dry markets crammed with people have been commonplace for centuries. However, the collision of such cultures was apparently not at the forefront of leaders' strategies. Nationalist and separatist ideologies springing from the current United States federal government and Brexit have exacerbated and vilified differences leaving the world vulnerable (Colantone \& Stanig, 2016; Giroux, 2017). By comparison, the world did not experience cataclysmic pandemics with two other novel viruses, the SARS-Cov-1 of 2003, and the MERS-COV of 2012.

A unique way of looking at the global pandemic is to consider the strata embedded in our society. To reflect on colliding cultures, we consider the work of Harvard trained biophysicists Dr. Donnella Meadows who commented that our cultures would have immense trouble together without further intervention, a problem that needed dire attention even 30 years ago (Meadows, 1990). She argued that if the world were only 1000 people, the following would occur. See Table 1.

Table 1

Meadow's summary of a global community, hypothetically $n=1000$

\begin{tabular}{llll}
\hline 584 & Asian & 64 & Speak Spanish \\
123 & African & 300 & Christians \\
95 & Europeans & 175 & Moslems \\
165 & Speak Mandarin & 128 & Hindus \\
86 & Speak English & 55 & Buddhists \\
86 & Speak Hindi & 200 & Have $3 / 4$ of wealth \\
& & 200 & Have only $2 \%$ of wealth \\
\end{tabular}


The one thing that clear on this 1000-person island, the community had enough nuclear power to "blow itself to smithereens many times over" (Meadows, 1991, para. 7). Of the 1000 people in Meadow's village, only 100 would have control of the weapons, while 900 watched anxiously on how the weapons were handled. These numbers are analogous to our current explosive pandemic. So many of our global citizens are watching anxiously, at times following the ill-informed advice to their peril that COVID-19 is a hoax. While the virus blows up the community, only a few leaders are in control; they must guide us through these unprecedented times with cultural competency, otherwise, parts of the global community will continue its battle with the disease.

Ironically, the early strategy of shelter in place also served to divide global communities further, yet not just along racial lines, but within socioeconomic structures. The "haves," that is those who have reliable Internet, jobs that can convert to home offices, and children whose schools can do the same, can withstand and afford the isolation. The "have-nots," those disenfranchised essential workers who have been advised to juggle their health concerns and economic stability are left with little choice but to enter the belly of the pandemic whale by reporting to front-line jobs with minor controls to stifle the virus. Again, as Meadows (1990) posited, the 'haves' thus those in control, are in the minority, while 'the have-nots" are much more vulnerable to the resulting economic instability.

The division continues for our youth with many parents of public school-aged youngsters who are scrambling and worried about leaders forcing the opening of schools in the fall 2020. In converse, parents who can afford to send their school-aged children to private schools are nestled in place with a relatively smooth transition to online learning, complete with the high-end laptops and appropriate bandwidth to sustain interactive remote instruction. Culturally intelligent leaders who are more concerned with the safety and environments of all citizens could have better prepared their respective administrations and constituents to be braced for the pandemic and understand that those in financially more fragile situations, such as Blacks and Hispanics, are more likely to work and live in communities with infrastructures that minimize protection from the virus. Our hope is that our children growing up in this pandemic learn from the mistakes of divisive leaders and instead prepare the world of colliding cultures.

The COVID-19 threat rolled across our globe during the spring of 2020. In the summer of 2020 , several communities are facing a relapse of the virus, with lines of people waiting for tests stretching for miles. The 
fifth largest economy on the planet, Los Angeles, California, is reeling from the need to resurrect another lock-down. Health care workers report another shortage of personal protective equipment (PPE) and record capacity in emergency rooms. The Center for Disease Control (CDC) has been battered in the news from a government that is pushing for economic recovery despite the risk to front line workers. Nonetheless, the CDC relying on science predicts that second wave in the United States (Sun, 2020) will bring even worse conditions if leadership and science cannot align in a common and data-informed message.

This common message should be a coordinated one from global leaders. Yet we still see that other countries have varied reactions, successes, and failures. Brazil has reported over 1.9 million cases and over 74,000 deaths, while the United States has reported 3.4 million cases and 133, 000 deaths. India and Mexico also report record deaths with 23,727 and 35,491 respectively. The United Kingdom has also reported over 45,000 deaths and France reported 35,000 deaths (Johns Hopkins, 2020). Comparatively, Canada has reported 8,790 deaths and Uruguay has lost only 30 people to the pandemic. The World Health Organization (WHO) highlights Cambodia for a swift and effective response to the virus (WHO, 2020). With the range of successes and recoveries regardless of race, religion, and region, some countries have effectively staved off the bio biohazard while other countries remain trapped in an endless cycle of infections. If the world could come together after World War II to develop the North Atlantic Treaty Organization (NATO) (Kaplan \& Kaplan, 2004) and even the Warsaw Pact (Mastny \& Byrne, 2005), though it is now defunct, to establish united and collaborative responses to prevent the threat of war, reasonably global leaders could work together to create a coordinated response in the battle against COVID-19.

\section{CONCLUSIONS/ IMPLICATIONS}

This short dialogue shows that we should not fear the collision of cultures. Whether recognize it or not, we have been interconnected at the speed of light in this modern society (Patrick \& Hollis 2018). We should have learned just how small our global community is from the Internet, weather, and other phenomena that confirm close proximity amongst humanity. The danger is not the collision, the mixture of environments, social mores, and traditions that inform a global community. The mistake our leaders have made, and many continue to make, is that humanity is not manifest in neatly individually wrapped societies, where one never influences the other; we are 
all interconnected and mutually dependent. Yet culturally we all need to understand that those with the most complex personas that drift away from traditional forms of power are the most susceptible to the ill effects (Hollis, 2018). The cultural collision, if embraced without fear and prejudice, would prevent existential threats, a realty first felt by the most vulnerable among us.

\section{REFERENCES}

Colantone, I., \& Stanig, P. (2016). Global competition and Brexit. BAFFI CAREFIN Centre Research Paper, (2016-44).

Giroux, H. A. (2017). White nationalism, armed culture and state violence in the age of Donald Trump. Philosophy \& Social Criticism, 43(9), 887-910.

Hollis, L. P. (2018). Bullied out of position: Black women's complex intersectionality, workplace bullying, and resulting career disruption. Journal of Black Sexuality and Relationships, 4(3), 7389.

Johns Hopkins (2020). Corona Virus Resource Center. https://coronavirus.jhu.edu/map.html

Kannan, R.S. (2018). Cultural Intelligence. Research Starters Education. http://connection.ebscohost.com/c/articles/45827545/culturalintelligence

Kaplan, L. S., \& Kaplan, L. (2004). NATO divided, NATO united: the evolution of an alliance. Greenwood Publishing Group.

Meadows, D. (1990). State of the global village. The Global Citizen. http://redrat.net/thoughts/global_village.htm

Mastny, V., \& Byrne, M. (Eds.). (2005). A cardboard castle? : an inside history of the Warsaw Pact, 1955-1991. Central European University Press.

Patrick, C., \& Hollis, L. (2018). Contentious Cloud Chatter: A Comparative Analysis of Aggressive Speech. Comparative Civilizations Review, 78(78), 8.

Sun, L. (2020). CDC director warns second wave of coronavirus is likely to be even more devastating. Washington Post. https://www.washingtonpost.com/health/2020/04/21/coronavirussecondwave-cdedirector/

World Health Organization (2020). Cambodia's effective rapid response to early COVID-19 cases due to early investments in health security systems. https://www.who.int/news-room/feature- 
stories/detail/cambodia-s-effective-rapid-response-to-early-covid19-cases-due-to-early-investments-in-health-security-systems

CLEA PATRICK is the executive secretary for the Bruce Haselrig Group and a founding member of the African American Heritage Society in Cambria County, Pennsylvania. Her commitment to social justice continues to inform the diversity training she provides to her local community.

BRUCE HASELRIG is the founder and president of the Bruce Haselrig Group. His expertise has led to cultural sensitive training of over 100 colleges and high schools in the last decade. Both practitioners may be reached at bhaselrig_group@yahoo.com. 